\title{
Pengembangan klon Sukun (Artocarpus altilis (Park.) Fosberg.) unggulan untuk mendukung ketahanan pangan
}

\author{
The development of Sukun (Artocarpus altilis (Park.) Fosberg.) clones \\ to support food security
}

\author{
Hamdan Adma Adinugraha $^{1 *}$ dan Dedi Setiadi ${ }^{1}$ \\ ${ }^{I}$ Balai Besar Penelitian dan Pengembangan Bioteknologi dan Pemuliaan Tanaman Hutan \\ Jl. Palagan Tentara Pelajar Km. 15, Purwobinangun, Pakem, Sleman, Yogyakarta 55582, Indonesia
}

\begin{abstract}
ABSTRAK
Sukun (Artocarpus altilis) merupakan jenis tanaman serbaguna yang bisa dimanfaatkan kayunya, kulit batang, buah dan daunnya. Produk utama sukun adalah buahnya sebagai salah satu sumber pangan potensial yang memiliki kandungan gizi cukup tinggi dan banyak dikonsumsi sebagai makanan tambahan bahkan makanan pokok tradisional seperti di negara-negara di kawasan Pasifik. Tantangan yang dihadapi dalam rangka pengembangan sukun sebagai sumber pangan alternatif bagi masyarakat antara lain mendapatkan ketersediaan bahan tanaman dari klon-klon sukun unggulan yang produksi buahnya tinggi dan memiliki kandungan gizi dan bahan kimia lainnya yang cukup baik sebagai sumber pangan maupun bahan obat. Berdasarkan hasil seleksi klon pada plot uji klon sukun di Gunungkidul Yogyakarta diperoleh 5 populasi sukun unggulan yang mewakili kultivar sukun yang ada di Indonesia yaitu sukun Cilacap, sukun Yogyakarta, sukun Bali, sukun Bone dan sukun Manokwari. Untuk menjamin ketersediaan bibit klon sukun unggulan dilakukan pengembangan teknik produksi bibit dengan teknik stek akar, stek pucuk dan stek batang di persemaian dengan persentase hidup 70-100\%. Selanjutnya dilakukan penyebarluasan informasi untuk meningkatkan upaya pengembangan sukun oleh masyarakat. Kegiatan penanaman sukun dilakukan untuk meningkatkan ketersediaan hutan cadangan pangan ke depan baik dilakukan secara mandiri maupun secara bekerjasama dengan para pihak yang berupaya mengembangkan penanaman sukun.
\end{abstract}

Kata kunci : sukun, hutan cadangan pangan, sumber pangan, teknik produksi bibit

\section{ABSTRACT}

Breadfruit (Artocarpus altilis) is one of multipurpose tree species that their wood, bark, fruit and leaves can be utilized for human life. The main product of breadfruit is its fruit as one of the potential food sources that has a fairly high nutrient content and is widely consumed as an additional food and even traditional staple foods such as in some countries the Pacific region. The challenge in developing breadfruit as an alternative food source for the community is to prepare the plant material of superior breadfruit clones which have high fruit production and have enough nutrients and chemicals as a source of food and medicinal ingredients. Based on the clones selection at the clonal test plantation in Gunungkidul, Yogyakarta obtained 5 excellent breadfruit populations representing breadfruit cultivars in Indonesia, namely Cilacap, Yogyakarta, Bali island, Bone and Manokwari. To ensure the availability of seedlings of superior breadfruit clones, the development of planting stocks production techniques is carried out by root cuttings, shoot cuttings and stem cuttings in the nursery that showed better growth succeess (70-100\%). Furthermore, information dissemination is carried out to increase efforts to develop breadfruit by the community / user. Breadfruit planting activities are carried out to increase the availability of food reserve forests in the future, both independently and collaboratively with stakeholders who interested in developing of breadfruit plantations.

Keywords: breadfruit, food reserve forest, food sources, planting stock production

\section{Pendahuluan}

Tanaman sukun (Artocarpus altilis) merupakan salah satu jenis tanaman yang banyak dikembangkan di berbagai negara (Elevitch \& Ragone, 2018). Di beberapa negara di kawasan Pasifik, buah sukun bahkan merupakan salah satu bahan makanan pokok dan menjadi komoditas andalan untuk ekspor (Ragone, 2011). Meskipun bukan

\footnotetext{
* Penulis korespondensi:

E-mail: hamdan_adma@yahoo.co.id
} 
sebagai bahan makanan pokok, masyarakat Indonesia telah lama mengenal dan membudidayakan tanaman sukun baik sebagai tanaman pekarangan maupun di kebun. Hal ini terbukti dengan adanya sebaran tanaman sukun sangat luas mulai dari Aceh sampai dengan Papua (Rajendran,1992). Tanaman sukun dimanfaatkan buahnya sebagai sumber bahan makanan yang memiliki kandungan gizi tinggi dan dapat diolah dengan bermacam-macam cara dari cara tradisional sampai modern (Ragone, 2011). Buah sukun dapat diolah menjadi tepung yang selanjutnya dapat diolah menjadi beraneka menu makanan yang bernilai ekonomi tinggi (Widowati, 2009; Supriati, 2010). Selain buahnya, pemanfaatan tanaman sukun terus diteliti dan dikembangkan dari bagian daun dan kulit batang sebagai bahan obat untuk mengatasi berbagai macam gangguan penyakit (Abdassah, dkk. 2009; Arung et al., 2009; Raman et al., 2012).

Pengembangan sukun di Indonesia umumnya masih secara tradisonal dengan memanfaatkan anakan dari daerah setempat (Adinugraha \& Setiadi, 2015). Terbatasnya informasi mengenai teknik budidaya dan ragam kultivar sukun yang ada di nusantara dan ragam pemanfaatan buah sukun menyebabkan pegembangan jenis tanaman ini tidak pesat. Padahal dengan sebarannya yang sangat luas di Indonesia sangat potensial untuk dikembangkan sebagai alternatif subtitusi bahan makanan pokok masyarakat (Supriati, 2010) Berdasarkan hasil pengamatan dari beberapa populasi diketahui adanya variasi morfologi dan kandungan gizi buahnya (Adinugraha \& Kartikawati, 2012). Oleh karena itu pengembangan ke depan diperlukan seleksi klon-klon sukun unggulan yang memiliki kandungan gizi Buah yang tinggi dan daya adaptasi yang lebar terhadap kondisi lingkungan tumbuhnya. Demikian pula diperlukan pengembangan iptek pembibitan yang mudah diterapkan oleh masyarakat dan dapat menghasilklan bibit dalam jumlah yang memadai untuk kegiatan penanaman.

Tujuan penelitian ini adalah penyediaan bibit klon sukun unggulan untuk mengembangkan tanaman sukun sebagai sumber pangan melalui pembangunan hutan cadangan pangan di beberapa lokasi dan penyebarluasan iptek pengembangan budidaya sukun kepada masyarakat.

\section{Metode Penelitian}

\section{Lokasi dan Waktu Penelitian}

Kegiatan seleksi klon sukun unggulan dilakukan di plot uji klon sukun di Kawasan Hutan Dengan Tujuan Khusus (KHDTK) Playen, Gunung Kidul Yogyakarta. Plot uji klon tersebut dibangun pada tahun 2003-2006 dengan menggunakan materi genetik yang dikoleksi dari berbagai sebaran tanaman sukun di Indonesia yaitu Banten, Sukabumi, Cilacap, Yogyakarta, Kediri, Banyuwangi, Bali, Mataram, Lampung, Bone, Malino, Sorong dan Manokwari. Kegiatan perbanyakan tanaman dilakukan di persemaian Balai Besar Penelitian dan Pengembangan Bioteknologi dan Pemuliaan Tanaman Hutan (BBPPBPTH) di Sleman, Yogyakarta.

\section{Bahan dan Alat}

Bahan tanaman berupa tegakan plot uji klon sukun umur 10 tahun di KHADTK Playen, Gunungkidul. Bahan tanaman untuk perbanyakan menggunakan akar untuk bahan stek akar yang diambil dari beberapa populasi unggulan terseleksi. Bahan-bahan lain yang digunakan yaitu media pasir, top soil, pupuk organik, zat pengatur tumbuh, bambu, plastik sungkup, polybag dan label. Peralatan yang digunakan antara lain gunting stek, parang, sekop, penggaris dan alat tulis.

\section{Prosedur Penelitian}

1) Seleksi klon sukun unggulan untuk kegiatan pengembangan lebih lanjut dilakukan di plot uji klon sukun di Gunungkidul dengan berdasarkan beberapa kriteria yaitu daya adaptasi tanaman di lokasi penanaman, tingkat pertumbuhan tanaman dan kandungan gizi buah sukun dari masing-masing lokasi.

2) Pengambilan bahan tanaman dari klon-klon sukun unggulan yang sudah dipilih dilokasi uji klon. Bahan tanaman yang diambil berupa akar yang berukuran diameter sekitar 1-3 cm. Dari setiap pohon induk diambil sebanyak 20 sampel akar yang kemudian dikelompokkan menjadi satu, kemudian diikat dan diberi label sesuai dengan nomor pohon induknnya.

3) Perbanyakan tanaman dilakukan dipersemaian dengan menerapkan teknik stek akar, stek pucuk dan stek batang. Penanaman stek akar sukun dilakukan pada media pasir dalam polybag yang disusun di bedengan persemaian dan selanjutrnya ditutup sungkup plastik untuk menjaga kelembaban udara $\pm 80 \%$ sehingga dapat memacu 
partumbuhan stek akar. Teknik stek pucuk dilakukan dengan menggunakan tunas/trubusan pada stek akar yang berumur 3-4 bulan, sedangkan teknik stek batang dilakukan dengan menggunakan batang bibit sukun di persemaian yang sudah berumur \pm 1 tahun.

4) Sosialisasi iptek pengembangan sukun dilakukan dalam rangka menyebarluaskan informasi teknik budidaya sukun mulai dari teknik pembibitan, kegiatan penanaman di lapangan sampai dengan informasi teknik pengolahan hasil buah sukun.

5) Pembangunan plot hutan cadangan pangan dilakukan dalam rangka menyediakan demplot-demplot tanaman sukun unggulan yang pembangunannya dilakukan secara bekerja sama dengan para pihak/pengguna baik instansi pemerintah, swasta, pondok pesantren dan masyarakat.

\section{Pengambilan dan Analisis Data}

Penelitian ini menggunakan metode deskriptif yaitu melakukan survey/pengamatan secara langsung terhadap semua karakter pertumbuhan tanaman untuk menggambarkan setiap kondisi tanaman dari masing-masing populasi asal sukun. Karakter pertumbuhan yang diamati yaitu persentase hidup tanaman, tinggi pohon, diameter batang, gejala serangan hama/penyakit dan produksi buahnya. Dipergunakan pula data hasil analisis kandungan gizi buah sukun dari masing-masing populasi seperti kadar air, karbohidrat, lemak, protein, pati, vitamin C, posfor, kalsium dan serat.

\section{Hasil dan Pembahasan}

\section{Seleksi Klon Sukun Unggulan}

Berdasarkan hasil seleksi yang dilakukan pada plot uji klon sukun di Gunungkidul diperoleh 5 populasi yang menunjukkan daya adaptasi terbaik terhadap kondisi lahan penanaman serta memiliki rerata tingkat pertumbuhan tanaman yang lebih baik dari populasi-populasi lainnya. Kelima populasi tersebut adalah sebagai berikut:

\section{1) Sukun Lokal Yogyakarta}

Tanaman sukun di Yogyakarta ada 2 kultivar yaitu sukun yang buah berbentuk bulat sampai lonjong dan tidak berduri dan sukun yang buahnya bulat dan berduri dengan ukuran buah yang lebih kecil serta rasanya lebih manis. Buah sukun yang tidak berduri diduga berasal dari daerah Cilacap, sedangkan sukun yang berduri dikenal dengan sukun lokal Yogyakarta seperti tampak pada Gambar 1. Sukun lokal beratnya beskisar antara 1-1,5 kg sedangkan sukun gundul dapat mencapai 2-4 kg/buah. Penyebaran sukun di Yogyakarta merata di seluruh kabupaten yang ada yaitu Bantul, Gunung Kidul, Sleman dan Kulonprogo. Tanaman sukun sudah umum dibudidayakakan oleh masyarakat sebagai tanaman pekarangan atau di kebun terutama untuk tipe buah sukun yang tidak berduri. Adapun tanaman sukun lokal sebarannya tidak merata yang terdapat di wilayah Sleman dan Gunung Kidul. Berdasarkan hasil analisis kandungan gizi per 100 gram daging buah sukun yang dilakukan di laboratorium diperoleh hasil sebagai berikut: kadar air 73,32,03\%, abu 1,03\%, karbohidrat 23,69\%, lemak 0,23\%, protein 1,73\%, pati $15,63 \%$, vitamin C 14,22 mg/100g, phosphor 49,50 mg/100g, kalsium 45,40 mg/100g dan serat kasar 1,40\% (Adinugraha \& Kartikawati, 2012).

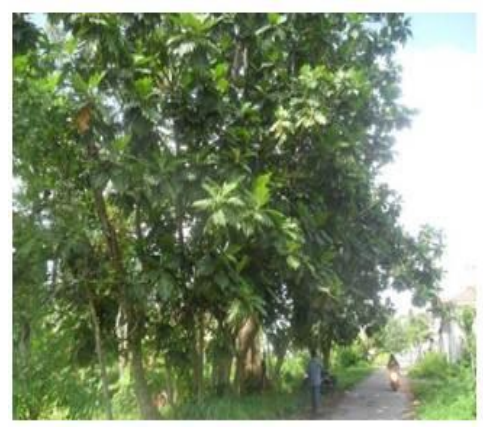

A

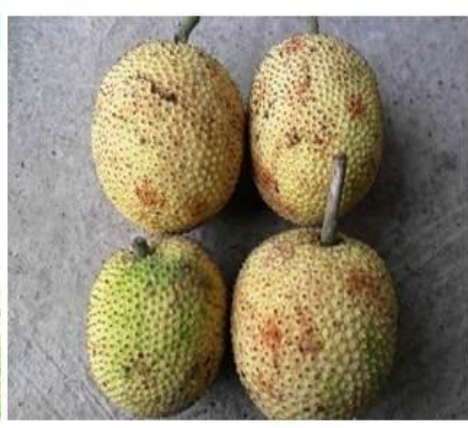

B

Gambar 1. Pohon induk (A) dan buah sukun lokal (B) dari Yogyakarta 


\section{2) Sukun Bone Sulawesi Selatan}

Penyebaran tanaman sukun di Sulawesi Selatan terdapat di kabupaten Gowa, Maros, Bone, Sopeng, Enrekang, Wajo dan Bulukumba. Buah sukun dari daerah-daerah tersebut menunjukkan kesamaan yaitu tipe buah lonjong dan beduri sampai tua/matang dengan warna kulit buah hijau muda. Sebaran tanaman sukun di Sulawesi Selatan relatif merata mulai dari dataran rendah sampai daerah datara tinggi/perbukitan. Masyarakat sudah turun temurun membudidayakan sukun sebagai tanaman pekarangan maupun di tegalan/kebun bercampur dengan jenis komoditas lainnya seperti coklat, kemiri, mangga, pisang, kelapa, tanaman pertanian/ semusim (ketela pohon dan ubi jalar). Bentuk buah sukun lonjong dengan ukuran sedang sampai besar yaitu panjangnya 14-20 cm, diameter buah 11-15 $\mathrm{cm}$ dan beratnya 850-1350 gram seperti disajikan pada Gambar 2. Hasil panen buah sukun umumnya dijual ke pasar dan sebagian dikonsumsi sendiri. Pengolahan buah sukun menjadi makanan ringan kripik sudah berkembang di masyarakat dan sudah dipasarkan secara luas ke wilayah Makassar dan sekitarnya. Hasil analisis kandungan gizi buahnya diperoleh kadar air buah $74,65 \%$, abu $1,23 \%$, kandungan karbohidrat $19,82 \%$, lemak $0,56 \%$, protein $2,50 \%$, pati $16,55 \%$, fosfor $31,68 \mathrm{mg} / 100 \mathrm{~g}$, kalsium $251,45 \mathrm{ppm}$, vitamin C 38,92 mg/100g dan serat kasar $1,64 \%$ (Adinugraha \& Kartikawati, 2012).

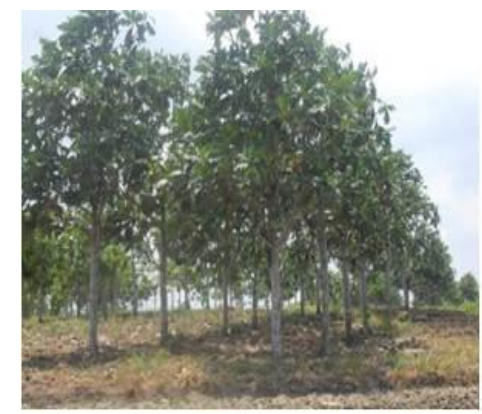

A

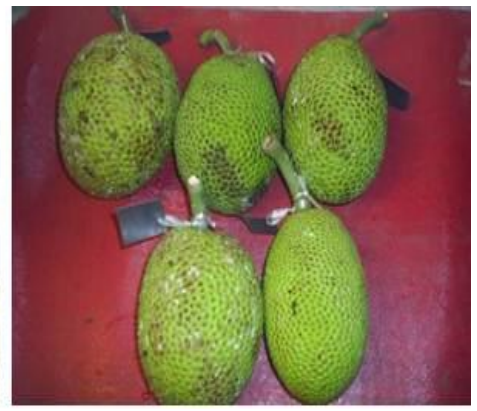

B

Gambar 2. Pohon induk (A) dan buah sukun (B) dari Bone, Sulawesi Selatan

\section{3) Sukun Papua Barat}

Sebaran sukun di Papua Barat relatif luas antara lain di Sorong dan Manokwari yang sudah terkenal dan menjadi sentra produksi makan ringan berupa keripik dari buah sukun sebagai oleh-oleh bagi para wisatawan yang berkunjung ke wilayah tersebut. Berdasarkan informasi dari masyarakat sukun yang paling enak berasal dari Pulau Jefman yang biasa dijadikan oleh-oleh khas daerah setempat. Penyebaran tanaman sukun umumnya banyak ditemukan di daerah pesisir pantai sampai dataran rendah di perkampungan penduduk dengan ketinggian 1-100 $\mathrm{m}$ di atas permukaan laut. Habitus pohon sukun di kawasan ini umumnya monopodian namun memiliki percabangan yang rendah dan sudut percabangan yang lebar. Musim buah sukun umumnya sekitar bulan Maret dan September. Buah sukun berbentuk lonjong dan berduri sampai tua/matang dengan ukuran sedang sampai besar dan berwarna hijau kekuningan seperti disajikan pada Gambar 3 (Setiadi \& Adinugraha, 2017).

Gambar 3. Pohon induk (A) dan buah sukun (B) dari Sorong, Papua Barat

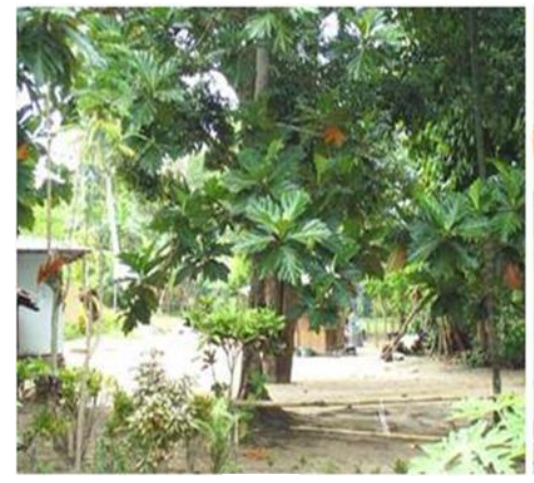

A

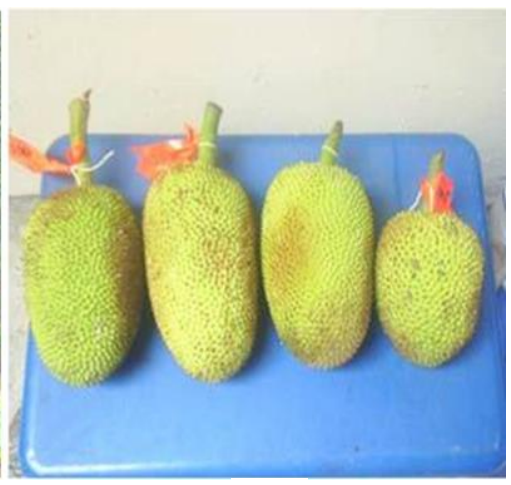

B 
Sebaran tanaman sukun di daerah Sorong terdapat di wilayah Sorong Daratan (Tanjung Kasuari, daerah Kampung Baru dan Kilo Sepuluh) dan Sorong Kepulauan seperti di P. Dom, P. Jefman, P. Buaya dan P. Soop. Hasil pengamatan di Manokwari juga sama dilaporkan bahwa sebaran tanaman sukun ditemukan mulai dari pesisir sampai daratan dengan ketinggian 1 s/d 44 m dpl antara lain di daerah Sanggeng, Kampung Suwen dan Amban di Distrik Manokwari. Hasil analisis kandungan gizi buah sukun dari Papua Barat adalah sebagai berikut: kadar air buah $75,96 \%$, abu $0,964 \%$, karbohidrat $18,19 \%$, lemak $0,58 \%$, protein $2,55 \%$, pati $16,94 \%$, fosfor $35,68 \mathrm{mg} / 100 \mathrm{~g}$, kalsium 89,84 ppm, vitamin C 47,74 mg/100g dan serat kasar 1,25\% (Adinugraha \& Kartikawati, 2012).

\section{4) Sukun Bali}

Bali dan Nusa Tenggara Barat merupakan salah satu daerah sebaran tanaman sukun meskipun sebarannya tidak merata di seluruh kawasan pulau. Pertumbuhan tanaman umumnya soliter atau tegakan kebun campuran dengan jenis tanaman lainnya. Jenis sukun dari kawasan ini adalah tipe buah sukun yang berbentuk bulat dan tidak berduri pada tua dengan warna kulit buah hijau kekuningan (Gambar 4). Sebaran sukun di Pulau Bali antara lain di Denpasar Selatan seperti di Desa Sempidi, Poan, Pregaya, Batang Asem dan Sading. Hasil analisis kandungan gizi buah sukun dari Bali diperoleh kandungan protein yang rata-rata lebih tinggi dibandingkan dengan sukun dari beberapa daerah lainnya yaitu berkisar antara $2,41-4,21 \%$ sedangkan umumnya kandungan protein pada buah sukun sekitar 1,3-2,0\% (Widowati, 2003). Hasil analisis kandungan gizi buah selengkapnya yaitu kadar air buah $74,78 \%$, abu $0,66 \%$, karbohidrat $14,047 \%$, lemak $0,65 \%$, protein $3,67 \%$,pati $10,18 \%$, fosfor $21,24 \mathrm{mg} / 100 \mathrm{~g}$, kalsium $165,18 \mathrm{ppm}$, vitamin C $26,28 \mathrm{mg} / 100 \mathrm{~g}$ dan serat kasar 1,69\% dengan jumlah kalori per 100 gram sekitar 72,89 kalori (Adinugraha \& Kartikawati, 2012).

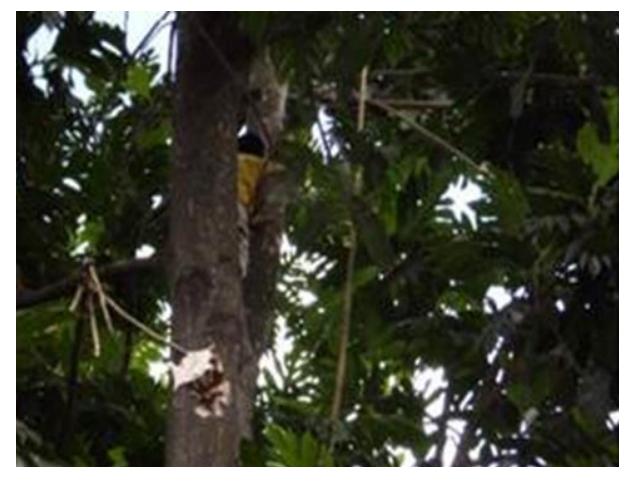

A

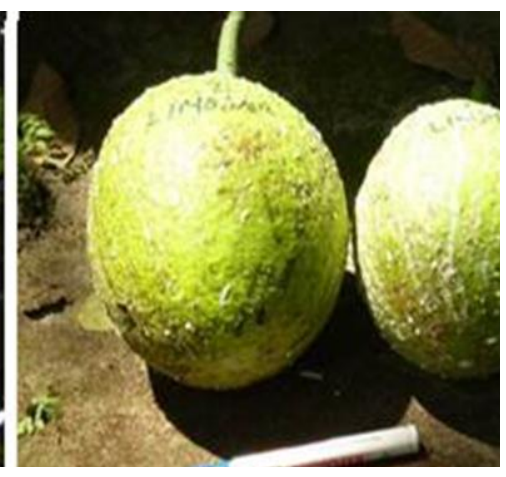

B

Gambar 4. Pohon induk (A) dan buah sukun (B) dari Bali

\section{5) Sukun Cilacap}

Penyebaran tanaman sukun di wilayah Cilacap, Jawa Tengah cukup luas dan relatif merata mulai dari daerah sekitar pesisir seperti Desa Widarapayung sampai ke dataran rendah. Masyarakat sudah lama membudidayakan sukun sebagai tanaman pekarangan. Daerah Cilacap juga merupakan salah satu sentra produksi buah sukun dan sentra produksi bibit sukun yang telah lama dikembangkan dan dipasarkan ke berbagai daerah lain di Jawa, Sumatera dan Kalimantan. Menurut (Pitoyo, 1992) sukun Cilacap berasal dari Pulau Bawean, Jawa Timur sehingga memiliki kesamaan morfologi pohon maupun buahnya dengan sukun yang berasal dari Kediri dan Banyuwangi yang merupakan daerah sentra produksi buah sukun di Jawa Timur (Badan Pusat Statistik, 2014).

Hasil pengamatan pohon sukun di Cilacap menunjukkan rerata tinggi pohon 11-16 m dan diameter batang/dbh 34,39-70,06 cm. potensi produksi buah sukun per tahun rata-rata 60-200 buah dengan 2-3 kali musim panen. Bentuk buah sukun termasuk tipe buah bulat - lonjong dan tidak berduri atau dikenal "sukun gundul" dengan ukuran buah bervariasi dari sedang sampai besar rata-rata beratnya 960-1475 gram, panjang buah 15-18 cm, lebar 13,8 cm dengan warna kulit buah hijau kekuningan seperti tampak pada Gambar 5. Hasil analisis kandungan gizi buah sukun Cilacap yaitu kadar air 67,42\%, abu 1,10\%, karbohidrat 29,24\%, lemak 0,30\%, protein 1,94\%, pati 20,49\%, 
posfor 52,51 mg/100g, kalsium 51,17 mg/100g, vitamin C 11,73mg/100g dan serat kasar 1,74\% (Adinugraha \& Kartikawati, 2012).

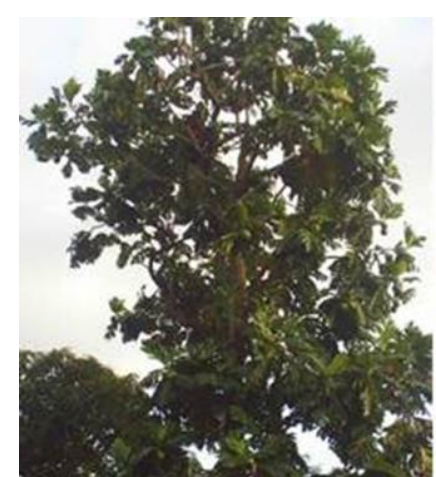

A

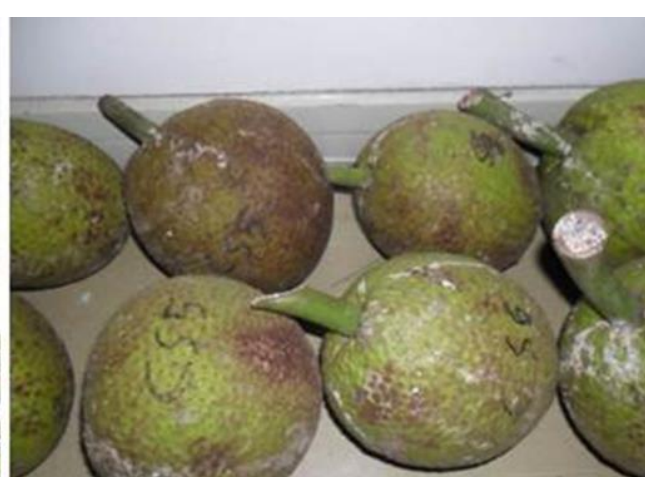

$\mathrm{B}$

Gambar 5. Pohon induk (A) dan buah sukun (B) dari Cilacap, Jawa Tengah

\section{Teknik Perbanyakan}

Pembibitan sukun dilakukan secara vegetatif karena buah sukun bersifat partinokarpi atau tidak memiliki biji (Deivanai \& Bhore, 2010). Teknik pembibitan yang dapat diterapkan di persemaian yaitu stek akar, stek pucuk, stek batang dan kultur jaringan (Mariska, dkk. 2004). Tingkat keberhasilan tumbuh stek akar sukun rata-rata 71,8085,20\% (Adinugraha, 2011). Tingkat keberhasilan tumbuh stek pucuk sukun dapat mencapai rata-rata 90-100\%. Sementara tingkat keberhasilan tumbuh stek batang sukun rata-rata 72-97\% (Adinugraha \& Wahyuningtyas, 2018). Pembibitan sukun dengan stek akar, stek pucuk dan stek batang dapat dilakukan dengan cara yang relatif mudah, dengan menggunakan media pasir sungai pada badengan yang ditutup sungkup plastik. Stek yang sudah berakar selanjutnya disapih ke media pertumbuhan berupa campuran tanah dan pupuk organik (kompos/pupuk kandang) dengan perbandingan 3:1 pada bedengan terbuka atau tidak disungkup. Waktu yang diperlukan untuk pertumbuhan tunas dan akar pada bedengan sungkup sekitar 2-3 bulan dan setelah itu bibit disapih ke media pertumbuhan berupa campuran tanah dan kompos (3:1) selanjutnya dipelihara di bedeng sapih selama 3-4 bulan. Bibit sukun yang sudah berumur 6 bulan di persemaian sudah siap untuk ditanam di lapangan (Gambar 6).

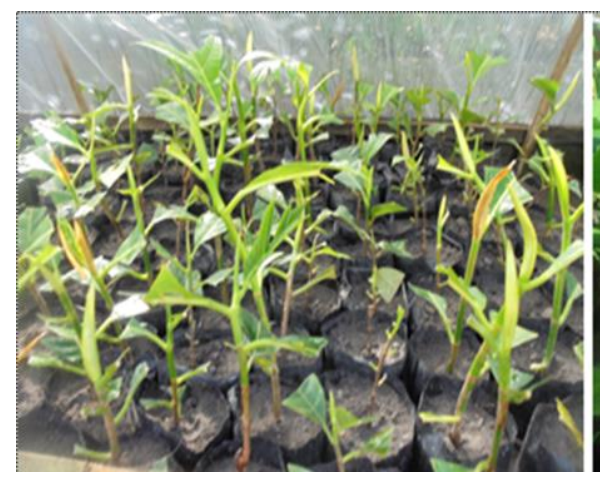

A

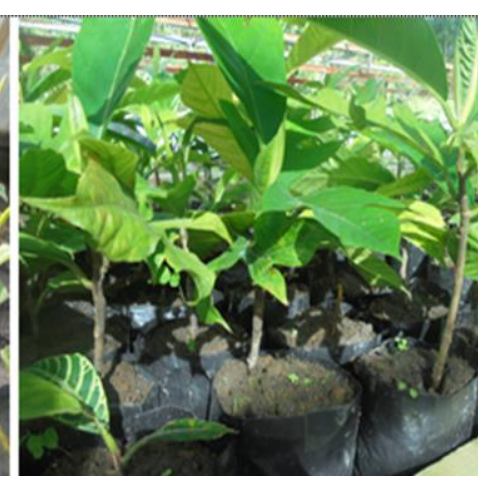

B

Gambar 6. Bibit sukun hasil stek batang di persemaian ( $\mathrm{A}=$ baru ditanam, $\mathrm{B}=$ umur 3 bulan)

\section{Penyebarluasan Iptek}

Penyebarluasan informasi iptek pengembangan budidaya sukun dilakukan dengan beberapa cara yaitu dalam bentuk penulisan karya tulis ilmiah (KTI), menyampaikan/ penjelasan materi kepada masyarakat/pengguna yang 
datang berkunjung ke BBPPBPTH di Sleman, Yogyakarta atau menjadi narasumber/pemakalah pada berbagai kegiatan pertemuan ilmiah nasional/internasional. Kegiatan yang dilakukan pada tahun 2016 - 2017 diantaranya yaitu Seminar Nasional Biodiversitas di Universitas Sebelas Maret di Surakarta, Seminar Nasional Sumber Daya Genetik di Badan Lingkungan Hidup Provinsi Jawa Tengah di Semarang, Seminar Nasional Silvikultur ke-5 di Universitas Lambung Mangkurat di Banjarbaru, Kalimantan Selatan dan lain-lain. Selain itu dilakukan penyebarluasan iptek melalui penerbitan karya tulis ilmiah pada jurnal atau majalah ilmiah nasional. Diharapkan melalui kegiatan informasi tentang iptek budidaya tanaman sukun dapat tersebar luas yang berdampak terhadap meningkatnya penanaman dan pemanfaatan tanaman sukun sebagai salah satu sumber pangan bagi masyarakat.

\section{Pembangunan Hutan Cadangan Pangan}

Kegiatan penyebarluasan materi genetik sukun unggulan telah dilakukan sejak tahun 2016 dalam rangka pembuatan tegakan hutan cadangan pangan di beberapa lokasi yang dilakukan secara bekerja sama dengan para pihak. Pembangunan hutan cadangan pangan sangat penting untuk meningkatkan ketahanan pangan masyarakat yang sering mengalami kerawanan pangan terutama desa-desa di sekitar hutan (Bangsawan \& Diprabowo, 2012). Selain itu juga dilakukan penanaman sendiri di Kawasan Hutan Dengan Tujuan Khusus (KHDTK) Playen, Gunungkidul dalam rangka penanaman pengayaan plot pertanaman uji klon sukun yaitu sebanyak 400 batang dengan jarak tanam $7 \times 7 \mathrm{~m}$. Luas lahan yang ditanami \pm 2 hektar, sehingga total luas lahan pertanaman klon sukun di Gununkidul mencapai \pm 11 ha. Pengembangan klon sukun unggulan di beberapa lokasi dilakukan dengan bekerjasama dengan beberapa pihak baik instansi pemerintah, swasta, lembaga pendidikan maupun masyarakat sebagaimana disajikan pada Tabel 1 dibawah ini.

Tabel 1. Realisasi penyebarluasan bibit klon sukun unggulan kepada masyarakat sampai tahun 2018

\begin{tabular}{|c|c|c|c|c|}
\hline No & Pelaksana & Jumlah Bibit & Jarak Tanam & Keterangan \\
\hline 1 & $\begin{array}{l}\text { Pemerintah Desa Ngarjosari Kec. } \\
\text { Tirtomoyo,Wonogiri, Jawa Tengah }\end{array}$ & 250 & $8 \times 8 \mathrm{~m}$ & $\begin{array}{l}\text { Penanaman tahun } 2016 \\
\text { Luas lahan } \pm 1,6 \text { ha }\end{array}$ \\
\hline 2 & $\begin{array}{l}\text { Rumpin Seed Source and Nursery Center } \\
\text { (RSSNC) di Bogor, Jawa Barat oleh } \\
\text { Direktorat Perbenihan Tanaman Hutan }\end{array}$ & 125 & $6 \times 6 \mathrm{~m}$ & $\begin{array}{l}\text { Penanaman tahun } 2017 \\
\text { Luas lahan } \pm 0,45 \text { ha }\end{array}$ \\
\hline 3 & Institut Seni Indonesia di Solo, Jawa Tengah & 100 & $6 \times 6 \mathrm{~m}$ & $\begin{array}{l}\text { Penanaman tahun } 2017 \\
\text { Luas lahan } \pm 0,36 \text { ha }\end{array}$ \\
\hline 4 & $\begin{array}{l}\text { Lembaga Pengembangan Teknologi Pedesaan } \\
\text { di DAS Pesusur }\end{array}$ & 150 & $6 \times 6 \mathrm{~m}$ & $\begin{array}{l}\text { Penanaman tahun } 2017 \\
\text { Luas lahan } \pm 0,54 \text { ha }\end{array}$ \\
\hline 5 & $\begin{array}{l}\text { Pemerintah Desa Wonokerto dan Girikerto } \\
\text { Kec. Turi, Sleman }\end{array}$ & 75 & $8 \times 8 \mathrm{~m}$ & $\begin{array}{l}\text { Penanaman tahun 2016-2017 } \\
\text { Luas lahan } \pm 0,27 \mathrm{ha}\end{array}$ \\
\hline 6 & $\begin{array}{l}\text { Pengurus Lingkungan Hidup Desa Donokerto } \\
\text { Kec. Turi Sleman }\end{array}$ & 50 & $8 \times 8 \mathrm{~m}$ & $\begin{array}{l}\text { Penanaman tahun } 2018 \\
\text { Luas lahan } \pm 0,32 \text { ha }\end{array}$ \\
\hline 7 & $\begin{array}{l}\text { Pondok Pesantren Ibnul Qoyim, Bantul } \\
\text { Yogyakarta }\end{array}$ & 25 & $8 \times 8 \mathrm{~m}$ & $\begin{array}{l}\text { Penanaman tahun } 2018 \\
\text { Luas lahan } \pm 0,16 \text { ha }\end{array}$ \\
\hline 8 & $\begin{array}{l}\text { Pemerintah Desa Tambak Boyo, Kec. } \\
\text { Mantingan, Ngawi Jawa Timur }\end{array}$ & 250 & $8 \times 8 \mathrm{~m}$ & $\begin{array}{l}\text { Penanaman tahun } 2018 \\
\text { Luas lahan } \pm 1,6 \text { ha }\end{array}$ \\
\hline 9 & $\begin{array}{l}\text { Pemerintah Desa Cemeng dan Kalak } \quad \text { Kec. } \\
\text { Donorejo, Pacitan, Jawa Timur }\end{array}$ & 250 & $8 \times 8 \mathrm{~m}$ & $\begin{array}{l}\text { Penanaman tahun } 2018 \\
\text { Luas lahan } \pm 1,6 \text { ha }\end{array}$ \\
\hline 10 & $\begin{array}{l}\text { Pusat Pengendalian Pembangunan Ekoregion } \\
\text { di Yogyakarta }\end{array}$ & 100 & $8 \times 8 \mathrm{~m}$ & $\begin{array}{l}\text { Penanaman tahun } 2018 \\
\text { Luas lahan } \pm 0,64 \text { ha }\end{array}$ \\
\hline
\end{tabular}

(Sumber: Setiadi, dkk. 2018)

Berdasarkan hasil pengamatan tanaman sukun di Gunungkidul pada umur 5 tahun, produksi buah per pohon sukun sebanyak 6-36 butir (Kartikawati, dkk. 2010). Menurut Widowati (2009) dalam satu buah sukun kandungan karbohidratnya dapat mencapai $28,2 \%$ sehingga sangat potensial bahan makanan pokok pengganti beras. Dari satu buah sukun yang beranya sekitar 1500 gram tersedia karbohidrat 365 gram yang cukup untuk memenuhi kebutuhan karbohidrat 3-4 orang dalam sekali makan. Mengingat sebarannya yang sangat luas di seluruh nusantara, maka 
pengembangan tanaman sukun merupakan salah satu upaya penting dalam mendukung ketahanan pangan nasional melalui program diversifikasi pangan.

\section{Kesimpulan}

Hasil seleksi klon sukun unggulan di Gunungkidul diperoleh 5 populasi unggulan yang dapat dikembangkan lebih lanjut dan dapat diperbanyak secara vegetatif dengan teknik stekakar, stek pucuk dan stek batang dengan tingkat keberhasilan tumbuh rata-rata lebih dari $70 \%$. Untuk pengembangan dimasyarakat diperlukan kerjasama dengan para pihak sehingga dapat terbangun plot-plot hutang cadangan pangan pada daerah-daerah yang memerlukan untuk mendukung ketahanan pangan dan meningkatkan pendapatan masyarakat.

\section{Ucapan Terima Kasih}

Penulis mengucapkan terima kasih kepada Balai Besar Penelitian dan Pengembangan Bioteknologi dan Pemuliaan Tanaman Hutan atas kesempatan yang diberikan dan dukungan finansialnya untuk penelitian ini. Penulis juga berterima kasih kepada ahli Bapak Susanto dan Bapak Ponimin yang telah banyak membantu dalam pelaksanaan kegiatan penyiapan bahan tanaman, pembibitan dan pengamatan pertumbuhan bibit di persemaian.

\section{Daftar Pustaka}

Abdassah, M., Sumiwi, S. A., \& Hendrayana, J. (2009). Formulasi Ekstrak Daun Sukun (Artocarpus altilis ( Parkins .) Fosberg ) Dengan Basis Gel Sebagai Antiinflamasi. J. Far. Indonesia, 4(4), 199-209.

Adinugraha, H. A. (2011). Pengaruh Umur Pohon Induk Dan Jenis Media Terhadap Pertumbuhan Stek Akar Sukun. Wana Benih, 12(1), 21-29.

Adinugraha, H. A., \& Kartikawati, N. K. (2012). Variasi morfologi dan kandungan gizi buah sukun. Wana Benih, 13(2), 99-106.

Adinugraha, H. A., \& Setiadi, D. (2015). Pengembangan Teknik Budidaya Sukun (Artocarpus altilis) Untuk Mendukung Pembangunan Hutan Cadangan Pangan. Prosiding Seminar Agroforestry, 59-64.

Adinugraha, H. A., \& Wahyuningtyas, R. S. (2018). Pertumbuhan Stek Batang Sukun Dari Lima Populasi Sebaran. Prosiding Seminar Nasional Silvikultur Ke-V, 307-311.

Arung, E. T., Wicaksono, B. D., Handoko, Y. A., Kusuma, I. W., Yulia, D., \& Sandra, F. (2009). Anti-cancer properties of diethylether extract of wood from Sukun (Artocarpus altilis) in human breast cancer (T47D) cells. Trop. J. of Pharm. Res., 8(4), 317-324. https://doi.org/10.4314/tjpr.v8i4.45223

Badan Pusat Statistik. (2014). Statistik Tanaman Buah-buahan Dan Sayuran Tahunan Indonesia Tahun 2013. Jakarta.

Bangsawan, I., \& Diprabowo, H. (2012). Hutan Sebagai Penghasil Pangan Untuk Ketahanan Pangan Masyarakat: Studi Kasus di Kabupaten Sukabumi. JURNAL Pen. Sos. dan Ekon. Kehut, 9(4), 185-197.

Deivanai, S., \& Bhore, S. J. (2010). Breadfruit (Artocarpus altilis Fosb.) An Underutilized and Neglected Fruit Plant Species. MId. East J. of Sci.c Res., 6(5), 418-428.

Elevitch, C. R., \& Ragone, D. (2018). Breadfruit Agroforestry Guide: Planning and implementaton for regenerative organic methods. Breadfruit Institute of the National Tropical Botanical Garden, Kalaheo,Hawaii and Permanent Agriculture Resources, Halualoa Hawaii.

Kartikawati, N. K., Adinugraha, H. A., Setiadi, D., \& Prastyono. (2010). Variasi Produktivitas dan Morfologi Buah Sukun (Artocarpus altilis) Pada Uji Klon di Gunungkidul. Prosiding Ekspose Hasil-Hasil Penelitian Balai Besar Penelitian Bioteknologi Dan Pemuliaan Tanaman Hutan, 97-104.

Mariska, I., Supriati, Y., \& Hutami, S. (2004). Mikropropagasi Sukun (Artocarpus communis Forst), Tanaman Sumber Karbohidrat Alternatif. Kumpulan Makalah Seminar Hasil Penelitian Balai Besar Penelitian Dan Pengembangan Bioteknologi Dan Sumberdaya Genetic. Badan Penelilitian Dan Pengembangan Pertanian. Bogor Pertanian, 180-188. 
Pitoyo, S. (1992). Budidaya Sukun. Yogyakarta: PT. Kanisius.

Ragone, D. (2011). Farm and Forestry Production and Marketing Profile for. Breadfruit Institute of the National Tropical Botanical Garden, Kalaheo,Hawaii and Permanent Agriculture Resources, Halualoa Hawai.

Rajendran, R. (1992). Arthocarpus altilis (Parkinson) Fosberg. Edible fruits and nuts: PROSEA: Plant Resources of South-East Asia. Bogor, Indonesia.

Raman, V., Sudhahar, D., \& Anandarajagopal, K. (2012). Preliminary Phytochemical Investigation and Screening of Antimicrobial Activity of Leaf Extract of Artocarpus altilis. Asian. J. of Biol. and Life Sci.s, 1(2), 104-107.

Setiadi, D., \& Adinugraha, H. A. (2017). Koleksi Materi Genetik Tanaman Sukun di Papua Barat. Wana Benih, $18(1), 1-9$.

Setiadi, D., Adinugraha, H. A., Santoso, H. B., \& Susanto. (2018). Pengembangan Klon Sukun Unggulan. Laporan Hasil Pengembangan. Balai Besar Penelitian dan Pengembangan Bioteknologi dan Pemuliaan Tanaman Hutan. Yogyakarta.

Supriati. (2010). Sukun sebagai sumber pangan alternatif substitusi beras. Iptek Pangan, 5(2), 219-231.

Widowati, S. (2009). Prospek Sukun ( Artocarpus communis ) sebagai Pangan Sumber Karbohidrat dalam Mendukung Diversifikasi Konsumsi Pangan. Pangan, XVIII(56), 67-75. 